\title{
KUALITAS HIDUP PEREMPUAN MENOPAUSE
}

\author{
Anggia Kargenti Evanurul Marettih \\ Fakultas Psikologi UIN Suska Riau \\ Email: anggiake@yahoo.co.id
}

\begin{abstract}
Menopausal problems related to physical and psychological aspects. Physical aspects, declining estrogen production leading to many reproductive disorders such as irregular menstruation (3-4 years before menopause), blooding to vasomotor disturbances that can affect the activities of women experiencing menopause. Psychological, menopausal women will experience emotional instability, along with concerns that might occur in the body with the end of her menstrual period. Emotional stability will be gained back once they get good information about the menopause. Positive self-concept as well as the support given by family and friends will be able to improve the quality of life for postmenopausal women. Consistency of self-concept will increase harmonization within the individual, which in turn will increase the happiness of individuals. Individual's quality of life will improve when there is an integration between self-esteem, self-concept, self-acceptance as well as the individuals of understanding and addressing the problems of life.
\end{abstract}

Kata Kunci : menopause, keluhan, psikologis, kualitas hidup

\section{PENDAHULUAN}

Persoalan kesehatan reproduksi bukan hanya mencakup persoalan kesehatan reproduksi perempuan secara sempit dengan mengaitkannya 
pada masalah seputar perempuan usia subur, kehamilan dan persalinan. Secara lebih spesifik, berbagai masalah dalam kesehatan reproduksi mulai dari perawatan kehamilan, pertolongan pada persalinan, infertilitas, penggunaan kontrasepsi, kehamilan tidak diinginkan dan aborsi, penyakit menular seksual dan HIV/AIDS, pelecehan dan kekerasan pada perempuan, perkosaan, layanan dan informasi pada remaja, serta menopause pada perempuan dewasa, merupakan bagian dari upaya memberikan pendidikan kepada masyarakat tentang pentingnya kesadaran kesehatan reproduksi bagi individu, khususnya bagi perempuan. Dengan demikian, dapat dikatakan bahwa seluruh tingkatan hidup perempuan merupakan fokus persoalan kesehatan reproduksi itu sendiri

Menurut Manuaba, ${ }^{1}$ sampai akhir abad 21, diperkirakan antara 8\%$10 \%$ penduduk Indonesia adalah lansia dan lansia perempuan akan lebih banyak dibandingkan dengan laki-laki. Kasdu menyatakan bahwa sekitar $25 \%$ dari penduduk perempuan Indonesia akan mencapai usia menopause di tahun 2000, tentu saja angka ini akan mengalami kenaikan setiap tahunnya. ${ }^{2}$ Badan Kesehatan Dunia atau WHO (World Health Organization) menyebutkan bahwa ledakan menopause pada tahun-tahun mendatang sulit sekali dibendung dan diperkirakan di tahun 2030 nanti ada sekitar 1,2 miliar perempuan yang berusia diatas 50 tahun. Sebagian besar dari mereka (sekitar $80 \%$ ) tinggal di negara berkembang dan setiap tahunnya populasi perempuan menopause meningkat sekitar tiga persen. ${ }^{3}$ Artinya kesehatan perempuan khususnya patut mendapatkan perhatian, sehingga akan meningkatkan angka harapan hidup dan tercapainya kebahagiaan serta kesejahteraan secara psikologis.

Menopause, seperti halnya menarche dan kehamilan, dianggap sebagai peristiwa yang sangat berarti bagi kehidupan perempuan. Menarche pada remaja perempuan menunjukkan mulai diproduksinya hormon estrogen, sedangkan menopause terjadi ketika ovarium tidak lagi menghasilkan atau tidak memproduksi hormon estrogen. Pada usia 45 tahun, indung telur mengalami penuaan sehingga tidak lagi sanggup memenuhi hormon estrogen. Seluruh sistem hormonal akan mengalami kemunduran secara perlahan-lahan, dan perubahan pengeluaran hormon menyebabkan berbagai perubahan fisik dan berdampak pada kondisi psikis perempuan dalam menghadapi fase menopause, ${ }^{4}$ dan secara alamiah akan berpengaruh terhadap hubungan seks suami istri.

Turunnya fungsi ovarium (sel telur) mengakibatkan hormon terutama estrogen dan progesteron sangat berkurang dalam tubuh kita. Kekurangan hormon estrogen ini menyebabkan keluhan-keluhan fisik 
maupun psikis yang akan mempengaruhi kualitas hidup perempuan. Kualitas hidup merupakan persepsi individu mengenai keberfungsian mereka di dalam bidang kehidupan. Jika hal ini tidak disikapi dengan tepat akan membuat diri yang bersangkutan merasa tidak nyaman dengan "situasi" yang memang sudah merupakan kodrat dirinya sebagi seorang perempuan. Benarkah anggapan bahwa masa menopouse merupakan masa penurunan kualitas hidup seorang perempuan? Tulisan ini mendiskusikan bagaimanakah sebenarnya kualitas hidup perempuan yang sudah menopouse.

\section{PEMBAHASAN}

\section{Menopause}

Kasdu mendefinisikan menopause sebagai sebuah kata yang mempunyai banyak arti, men dan pauseis adalah kata Yunani yang pertama kali digunakan untuk menggambarkan berhentinya haid. ${ }^{5}$ Rahman mengatakan menopause terjadi pada usia menjelang 50 tahun yang ditandai denngan berhentinya haid terakhir dari uterus yang dipengaruhi oleh hormon-hormondari otak dan sel-sel telur. ${ }^{6}$ Menurut Drajat, menopause sebagai peralihan masa reproduksi ke masa nonreproduksi (tua) dimana kemampuan alat-alat reproduksinya mulai menurun yang disebabkan berkurangnya hormon estrogen dan progesterone yang mulai memegang peranan sangat penting dalam berbagai aktivitas tubuh. ${ }^{7}$ Baziad menyebutkan menopause sebagai pendarahan rahim yang masih diatur oleh fungsi hormon indung telur. ${ }^{8}$ Istilah menopause digunakan untuk mengatakan suatu perubahan hidup dan pada saat itulah perempuan mengalami periode terakhir masa haid. Menopause adalah saat dimana tidak ada lagi telur yang masuk lagi sehingga tidak direproduksi oleh indung telur hormon estrogen dan progesteron, maka perempuan itu tidak dapat hamil lagi. Takesihaeng menyatakan masa menopause adalah keadaan dimana seseorang berhenti dari masa haidnya selamanya. Menopause berarti berakhir dari kesuburan dan peralihan menjadi seorang perempuan tua, pada suatu masa menopause berarti akhir daya tarik seksual dan dalam beberapa masyarakat primitif masih diartikan sebagai penurunan pada perempuan tua yang dianggap netral secara seksual. ${ }^{9}$

Secara singkat dapat dikatakan bahwa menopause merupakan suatu proses peralihan dari masa produktif menuju perubahan secara perlahan-lahan kemasa non produktif yang disebabkan oleh berkurangnya hormon estrogendan progesteron seiring dengan bertambahnya usia. 
Umur seorang perempuan mengalami fase menopouse sangat bervariasi. Secara umum, 3,6\% perempuan memasuki fase menopouse pada usia 45 tahun, $96,4 \%$ pada usia 50 dan $96,6 \%$ pada usia 55 tahun. Capat atau lambat masa memasuki fase menopouse bagi seorang perempuan menurut Blackburn dan Davidson ${ }^{10}$ dipengaruhi oleh beberapa faktor. Faktor tersebut antara lain: (a) umur sewaktu mendapat haid pertama kali (menarche). Penelitian menemukan adanya hubungan antara umur pertama mendapat haid dengan umur sewaktu memasuki menopause. Semakin muda umur sewaktu mendapat haid pertama kali, semakin tua usia memasuki menopause, (b) kondisi kejiwaan dan pekerjaan. Hasil penelitian juga menunjukkan perempuan yang tidak menikah dan bekerja, umur memasuki menopause lebih muda dibandingkan dengan perempuan sebaya yang bekerja dan menikah, (c) jumlah anak, makin sering melahirkan, makin tua baru memasuki menopause, (d) penggunaan obat-obat keluarga berencana (KB), karena obat-obat $\mathrm{KB}$ memang menekan fungsi hormon dari indung telur, kelihatannya perempuan yang menggunakan pil KB lebih lama baru memasuki umur menopause, (e) merokok, perempuan perokok kelihatannya akan lebih muda memasuki usia menopause dibandingkan dengan perempuan yang tidak merokok, (f) cuaca dan ketinggian tempat tinggal dari pemukiman laut. Perempuan yang tinggal di ketinggian lebih dari 2000-3000 M dari permukaan laut lebih cepat 1-2 tahun memasuki usia menopause dibandingkan dengan perempuan yang tinggal diketinggian < $1000 \mathrm{M}$ dari permukaan laut, (g) sosio-ekonomi, menopause juga dipengaruhi oleh faktor status sosio ekonomi, di samping pendidikan dan pekerjaan suami. Begitu juga hubungan antara tinggi badan dan berat badan perempuan yang bersangkutan juga termasuk kepada faktor sosio ekonomi.

\section{Gejala dan Keluhan yang Terjadi Akibat Penurunan Produksi Hormonal}

Menopause terjadi dalam masa klimakterium, sebuah masa dimana terjadi peralihan dari fase reproduktif ke fase non-reproduktif. ${ }^{11}$ Perubahan-perubahan tersebut biasanya berlangsung dua sampai lima tahun, dan pada umumnya terjadi pada perempuan antara umur 45 sampai 55 tahun. Periode perubahan tersebut dapat juga disebut sebagai climacteric atau sering disebut dengan perubahan dalam hidup (masa transisi). ${ }^{12}$

Selama fase menopause akan terjadi beberapa gejala yang disertai keluhan-keluhan yang kerap kali membuat perempuan menjadi gelisah 
dan merasa tertekan akibat perubahan yang signifikan terhadap sistem hormonal sehingga membuat ketidaknyamanan. Gejala- gejala serta keluhan yang menyertai fase menopause, antara lain sebagai berikut: ${ }^{13}$

Keluhan fisik

Tidak semua keluhan fisik dapat terjadi pada perempuan, namun keluhan yang paling dominan dan sering terjadi pada perempuan adalah keluhan pada jantung, pada alat kelamin, fungsi motorik, fungsi sensoris, fungsi hormonal, dan fungsi tulang.

Keluhan pada jantung dan pembuluh darah terefleksi pada kulit yang terasa kering, keriput, dan longgar dari ototnya, badan dan wajah terasa panas, terjadi perubahan sirkulasi ada wajah yang dapat melebar ke tengkuk berwarna merah, hot flushes. Arus panas biasanya timbul pada saat haid mulai berkurang dan berlangsung sampai haid benar-benar berhenti. Munculnya hot flases ini sering diawali pada daerah dada, leher atau wajah menjalar ke beberapa daerah tubuh yang lain.14 Jantung mudah berdebar-debar, terjadi tekanan darah tinggi yang dapat berlanjut pada gangguan jantung koroner.

Keluhan pada alat kelamin bisa berupa liang senggama terasa kering, sulit menerima rangsangan karena sensitivitasnya juga menurun, epitel liang senggama dan sekitarnya mulai menipis sehingga mudah terkena infeksi, dalam melakukan hubungan seks terjadi dispareunia dan elastisitas sudah menurun hingga terasa longgar. Keadaan ini membuat hubungan seksual terasa sakit dan tidak nyaman.

Keluhan fungsi motorik adalah berupa otot motorik mulai melemah, koordinator gerakan mulai kurang tepat, pegangan sering terlepas, tubuh sering gemetar, artikulasi suara mengalami gangguan sehingga sering keseleo jika berbicara. Pada fungsi sensoris dapat berupa kemunduran sistem saraf sensoris dapat menyebabkan gangguan sirkulasi darah dan mengakibatkan timbulnya keluhan klinis dan gangguan fungsi perabaan. Keluhan pada sistem hormonal adalah sistem hormonal yang mengalami kemunduran/penuruan mempengaruhi metabolisme tubuh yang juga mengalami kemunduran. Penyakit metabolisme pada masa menopause adalah cepat menjadi gemuk, diperburuk dengan perilaku makan yang sembarangan dan tidak memperhatikan kadar gizi. Keluhan pada fungsi saraf, bahwa degenerati sel saraf menyebabkan kemunduran fungsi dan mengakibatkan keluhan pada pancaindera. Gangguan pada fungsi tulang adalah proses penuaan yang dapat menguras kalsium, sehingga menyebabkan pengeroposan tulang. Hal ini akan menimbulkan rasa nyeri ada persendian tulang. 
Ada beberapa gejala yang menandai menopause yang disebut fase preliminer, yaitu: 1) Menstruasi yang tidak lancar dan tidak teratur, yang datang lebih lambat atau lebih awal, 2) Kotoran, haid yang keluar banyak sekali ataupun sangat sedikit, 3) Muncul gangguan-gangguan vasomotoris, yang berupa penyempitan atau pelebaran pembuluhpembuluh darah, 4) Merasa pusing, disertai sakit kepala terus menerus, 5) Keringat berlebih, yaitu berkeringat yang tidak ada henti-hentinya, 6) Neuralgia, yaitu gangguan atau sakit syaraf dan lain-lain.

Keluhan-keluhan antara satu perempuan dengan perempuan lain tidak selalu sama. Hal ini disebabkan efek biologis di jaringan hormon estrogen melalui reseptor estrogen yang di dalam tubuh didapat reseptor estrogen alpha dan beta. Jumlah reseptor estrogen alpha dan beta yang tidak sama pada setiap perempuan dan adanya reaksi individual akibat rendahnya estrogen menyebabkan gejala menopause yang berbeda. Umumnya gejolak panas, susah tidur, gelisah, lekas marah, pelupa, nyeri tulang belakang dirasakan pada hampir sebagian besar perempuan menopause. 15

Akibat jangka panjang yang harus diperhatikan pada perempuan menopause adalah osteoporosis (tulang keropos), penyakit jantung koroner, stroke, dan pikun. Kalau kondisi ini dibiarkan dapat mengganggu aktivitas sehari-hari dan menurunkan kualitas hidup perempuan.

\section{Keluhan psikologis}

Keluhan psikologis yang menonjol ketika menopause ditandai dengan sikap yang mudah tersinggung, suasana hati (mood) yang tidak menentu, sering lupa, cemas, sukar tidur, tertekan, gugup, kesepian, tidak sabar, tegang (tension), stress, dan depresi. Ada juga lansia yang kehilangan harga diri karena menurunnya daya tarik fisik dan seksual, mereka merasa fidak dibutuhkan oleh suami dan anak-anak mereka, serta merasa kehilangan femininitas karena fungsi reproduksi yang hilang.

Gejala mudah tersinggug lebih mudah terlihat dibandingkan kecemasan. Perempuan lebih mudah tersinggung dan marah terhadap sesuatu yang sebelumnya dianggap tidak menggangu. Dalam suasana ini, perempuan menjadi sangat menyadari proses mana yang sedang berlangsung dalam dirinya. Perasaan menjadi sangat sensitif terhadap sikap dan perilaku orang-orang ada di sekitarnya, terutama jika sikap dan perilaku tersebut dipersepsikan sebagai menyinggung proses penerimaan yang sedang terjadi dalam dirinya.

Kecemasan yang timbul di masa menopause sering dihubungkan dengan adanya kekhawatiran dalam menghadapi situasi yang 
sebelumnya tidak pernah dikhawatirkan. Menurut Blackburn and Davidson $^{16}$ simptom kecemasan ini meliputi; (a) suasana hati yaitu keadaan yang menunjukkan ketidaktenangan psikis, seperti mudah marah, perasaan sangat tegang, (b) pikiran yaitu keadaan pikiran yang tidak menentu, seperti: khawatir, sukar konsentrasi, pikiran kosong, membesar-besarkan ancaman, memandang diri sebagai sangat sensitif, merasa tidak berdaya, (c) motivasi yaitu dorongan untuk mencapai sesuatu, seperti: menghindari situasi, ketergantungan yang tinggi, ingin melarikan diri, lari dari kenyataan, (d) perilaku gelisah yaitu keadaan diri yang tidak terkendali seperti: gugup, kewaspadaan yang berlebihan, sangat sensitif dan agitasi, (e) reaksi-reaksi biologis yang tidak terkendali, seperti: berkeringat, gemetar, pusing, berdebar-debar, mual, mulut kering.

Pada masa menopause, tidak ada orang yang bisa lepas sama sekali dari rasa was-was dan cemas, termasuk para lansia menopause. Ketegangan perasaan atau stress selalu beredar dalam lingkungan pekerjaan, pergaulan sosial, kehidupan rumah tangga, dan bahkan menyelusup ke dalam tidur. Demikian juga dengan gejala depresi di masa menopause. Perempuan yang mengalami menopause sering merasa sedih, karena kehilangan kemampuan untuk bereproduksi, sedih karena kehilangan kesempatan untuk memiliki anak, sedih karena kehilangan daya tarik. Perempuan merasa tertekan karena kehilangan seluruh perannya sebagai perempuan dan harus menghadapi masa tuanya.

Perubahan psikologis yang terjadi pada perempuan menopause sangat berpengaruh pada kehidupan sosial, terutama hubungan dengan suami, anak-anak, dan anggota keluarga lainnya. ${ }^{17}$ Tidak jarang perubahan fisik dan psikologis perempuan menopause menimbulkan konflik antara perempuan tersebut dengan pasangannya. Suami mengalami kegundahan untuk menghadapi istrinya yang sering mengalami perubahan emosi. Perubahan emosi yang signifikan tersebut dapat pula menakutkan bagi para suami.

Perempuan dalam masa menopouse akan sering merasakan kekecewaan terhadap pasangan. Ia beranggapan bahwa pasangannya tidak lagi ideal dan tidak lagi romantis. Pasangan akan dinilai tidak dapat mengerti akan keadaan dirinya yang dianggap sudah tidak lagi atraktif. Bahkan menganggap suaminya akan berpaling atau melakukan selingkuh dengan perempuan lain. Selanjutnya, intimasi hubungan terhadap pasangan juga mulai dirasakan berkurang sehingga sering terjadi argumentasi antara perempuan menopause dan pasangannya. Hunter dan Coope menyatakan bahwa akibat dari konflik dapat menimbulkan kesalah pahaman akan sering terjadi antara perempuan dan pasangan. 
Banyak hasil penelitian menemukan bahwa, gejala-gejala menopause akan mempengaruhi kepuasan pernikahan pada pasangan suami istri. ${ }^{18}$

Kondisi emosional yang tidak stabil ini akibat pengaruh perubahan hormon dalam tubuh atau karena faktor yang sifatnya sangat individual. Selain itu, fase menopause sering berbarengan dengan keadaan menegangkan lain dalam kehidupan perempuan seperti merawat orang tua lanjut usia, memasuki masa pensiun, melihat anak-anak tumbuh dewasa dan meninggalkan rumah serta penyesuaian-penyesuaian lain dalam kehidupan setengah baya.

\section{Mitos-Mitos Menopouse}

Kebanyakan mitos atau kepercayaan yang berkembang dalam masyarakat tentang menopause begitu diyakini sehingga menggiring perempuan untuk mengalami persepsi negatif saat mengalami menopause. Mitos atau keyakinan yang tidak rasional tentang menopause tersebut antara lain: Pertama, perempuan yang mengalami menopause otomatis berpredikat menjadi tua atau waktunya sudah lewat. Dengan berhentinya menstruasi, berarti perempuan tidak lagi mampu melahirkan anak, berarti tidak lagi mampu mengemban tugas/peran sebagai penerus generasi. Di samping itu dengan menurun bahkan berhentinya hormon estrogen akan berpengaruh pada hilangnya tanda-tanda kecantikan yang selama ini merupakan ciri khas perempuan yang dibanggakan.

Kedua, menopause dikaitkan dengan lengsernya peran sebagai istri bagi suami dan ibu bagi anak-anaknya. Sebagian besar perempuan mengalami menopause, hampir bersamaan waktunya dengan pencapaian karir puncak suaminya dalam pekerjaannya. Dalam kondisi ini, kebanyakan suami disibukkan dengan urusan pekerjaan sehingga waktu untuk istri berkurang. Sebagian besar anak-anaknyapun sudah menginjak usia remaja atau dewasa awal. Mereka sibuk dengan kegiatannya, sehingga tidak lagi merusuhi ibunya bahkan ada kesan anak tidak lagi membutuhkan ibunya. Bagi perempuan yang selama ini mengabdi total pada keluarga berkurangnya kerepotan mengurus suami dan anak, akan menimbulkan perasaan bahwa dirinya sudah tidak berharga dan tidak dibutuhkan lagi. Perasaan bahwa dirinya tidak dibutuhkan dan tidak dihargai ini akan menurunkan bahkan menghentikan keinginannya untuk melakukan aktivitas. Ia pun akan makin mengisolir dan menyingkir dari aktivitas sosial dan kemasyarakatan.

Ketiga, perempuan yang mengalami menopause, kehilangan daya tarik seksualnya dan menurun aktivitas seksualnya. Ada beberapa perempuan yang beranggapan sesudah menopause, tidak bisa memberi 
kepuasan seksual bagi suaminya. Ia pun tidak dapat menikmati hubungan intim dengan suaminya, karena jaringan genitalnya berkurang elasitisitasnya. Bahkan ada anggapan perempuan yang sudah menopause seyogyanya tidak melakukan hubungan seksual karena akan mengakibatkan munculnya penyakit. Keyakinan ini menggiring perempuan untuk mengurangi atau menghindari aktivitas seksual, yang akan berpengaruh pada berkurangnya keharmonisan hubungan suami istri. Kondisi ini akan memicu munculnya problem suami istri yang lebih komplek.

Keempat, mitos lainnya yaitu bahwa periode menopause sama dengan periode goncangan jiwa, yaitu munculnya gejala rasa takut, tegang, sedih, lekas marah, mudah tersinggung, gugup, stres dan depresi. ${ }^{19}$

\section{Kualitas Hidup Perempuan Menopause}

Kualitas hidup biasanya memiliki arti yang berbeda-beda tergantung dari konteks yang akan dibicarakan dan digunakan. Di dalam bidang kesehatan dan aktivitas pencegahan penyakit Coons \& Kaplan (dalam Sarafino, 1994) mengartikan kualitas hidup sebagai suatu pandangan umum yang terdiri dari beberapa komponen dan dimensi dasar yang berhubungan dengan kesehatan diantaranya keadaan dan fungsi fisik,keadaan psikologis, fungsi sosial dan penyakit serta perawatannya. ${ }^{20}$

Cohen \& Lazarus (dalam Sarafino, 1994) menyebutkan bahwa kualitas hidup adalah tingkatan yang menggambarkan keunggulan seorang individu yang dapat dinilai dari kehidupan mereka.Keunggulan individu tersebut biasanya dapat dinilai dari tujuan hidupnya, kontrol pribadinya, hubungan interpersonal, perkembangan pribadi, intelektual dan kondisi materi. ${ }^{21}$

Lebih spesifik lagi, Fayers \& Machin dalam Kreitler \& Ben (2004) mendefinisikan kualitas hidup sebagi penilaian individu terhadap posisi mereka di dalam kehidupan, dalam konteks budaya dan sistem nilai dimana mereka hidup dalam kaitannya dengan tujuan individu, harapan, standar serta apa yang menjadi perhatian individu..$^{22}$

Pendapat yang dikeluarkan oleh Fayers \& Machin senada dengan definisi yang telah ditetapkan oleh badan kesehatan dunia WHO yang menyebutkan bahwa kualitas hidup adalah persepsi individu mengenai posisi individu dalam hidup dalam konteks budaya dan sisitim nilai dimana individu itu hidup dan hubungannya dengan tujuan, harapan, standar yang ditetapkan dan perhatikan orang. ${ }^{23}$ 
Jika dikaitkan menopouse dengan dimensi kualitas hidup yang telah dikeluarkan oleh $\mathrm{WHO}$, maka jelas kualitas hidup perempuan yang menopouse mengalami penurunan. Hal ini disebabkan ketika fase menopouse seluruh dimensi tersebut mengalami perubahan-perubahan. Fase ini terjadi secara berangsur-angsur yang semakin hari semakin jelas penurunan fungsi kelenjar indung telurnya. Oleh karena itu, memasuki usia 40 sampai 50 tahun sering dijadikan momok yang menakutkan bagi perempuan. Secara psikologis, kekhawatiran ini dapat berawal dari pemikiran bahwa dirinya akan menjadi tidak sehat, tidak bugar dan tidak cantik. Kondisi tersebut memang tidak menyenangkan bagi perempuan.

Kadangkala, diantara kaum perempuan yang memasuki masa menopause ada yang mengalami goncangan. Tidak puas dengan keadaan, kurang bergairah dilanda rasa kesepian, takut ditinggal suami, khawatir bahwa rumah tangga akan terancam, atau bahkan segera akan menjadi seorang janda ${ }^{24}$. Efek lain yang timbul adalah kekhawatiran menjadi tua dan akan berkurang daya tariknya. Rasa kurang daya tarik diwujudkan dalam bentuk mudah tersinggung atau bahkan marah yang meledakledak, peka dan gampang berubah-ubah.

Perobahan lain yang tidak kalah pentingnya, dan sering menjadi pemicu utama dalam hal kegoncangan dalam rumah tangga, adalah menurunya dorongan seksual. Hal ini disebabkan pada masa menopouse kemampaun organ-organ seksual perempuan mengalami kemunduran. Akibatnya, pasangan merasa tidak puas yang akhirnya menggiring terjadinya perselingkuhan. Seksolog Boyke Dian Nugroho menyebutkan bahwa seks merupakan salah satu kebutuhan vital dalam kehidupan rumah tangga. Karena itu, tidak mengherankan jika banyak perselingkuhan terjadi ketika istri berada pada fase menopouse. Bibit-bibit perselingkuhan dapat muncul ketika suami istri tidak lagi bisa mencocokkan perbedaan sifat keduanya, tidak ada komunikasi, tidak bisa memecahkan konflik, dan tidak ada kepuasan seks. Data menunjukan $42 \%$ yang berselingkuh adalah mereka yang istrinya menopause,"25.

Peristiwa menopouse merupakan peristiwa alamiah yang harus dilalui oleh setiap perempuan. Sayangnya, informasi yang benar mengenai hal tersebut sepertinya belum tersosialisasi dengan baik di tengah-tengah masyarakat, justru, mitos-mitos yang kebenarnnya masih dipertanyakan lebih banyak diterima. Hal ini menyebabkan ada perempuan yang bersikap pisimis dalam kehidupan setelah memasuki usia menopouse.

Menurut Hawari, peristiwa menopause sama halnya seperti peristiwa menarche dan kehamilan yang dianggap sebagai peristiwa yang 
sangat berarti bagi kehidupan perempuan. Menopause adalah suatu fase dari kehidupan seksual perempuan, dimana siklus menstruasi berhenti. Bagi seorang perempuan, dengan berhentinya menstruasi ini berarti berhentinya fungsi-fungsi organ reproduksi, namun tidak berarti peranannya dalam melayani suami di bidang kebutuhan seksual berhenti dengan sendirinya ${ }^{26}$

Seksualitas adalah suatu keinginan untuk menjalin hubungan, kehangatan, atau cinta dan perasaan diri secara menyeluruh pada individu, meliputi memandang dan berbicara, berpegangan tangan, berciuman, atau memuaskan diri sendiri, dan sama-sama menimbulkan orgasme $^{27}$. Studi yang dilakukan oleh Dimsdale University AS, menunjukkan bahwa tidak semua perempuan menopause mengalami penurunan hasrat seksual, 39\% perempuan berusia 61-65 tahun memiliki aktivitas seksual seperti $27 \%$ perempuan berumur $66-71$ tahun, $13 \%$ perempuan menopause mempunyai hasrat lebih tinggi dibandingkan ketika masih muda ${ }^{28}$

Studi yang lain juga menunjukkan bahwa Hubungan seks tetap dapat dilakukan meskipun usia telah lanjut. Menopause hanyalah akhir kesuburan seorang perempuan atau akhir dari kemampuan untuk hamil. Akibat kekurangan estrogen, vagina menjadi kering dan mudah cedera, sehingga terasa sakit sewaktu bersenggama. Hal ini bisa diatasi dengan terapi hormonal, krem vagina, dan membiasakan diri berhubungan secara rutin seperti dulu.

Kebanyakan pakar seksiologi berpendapat bahwa sebenarnya bukan faktor fisik yang menjadi penyebab perempuan menopouse tidak mau berhubungan seks, masalah utamanya adalah faktor psikis. Ketika menopouse, perempuan mempunyai rasa takut, gelisah, tegang, tidak percaya diri dan khawatir dirinya tidak semenarik dan seprima dulu. Alasan bahwa badan lemah dan tidak bergairah hanyalah alasan untuk menutupi ketakutan dan kekhawatiran tersebut. Apabila, perempuan bersikukuh dengan pendiriannya ini (tidak mau berhubungan), segala masalah bisa saja terjadi dan memicu keretakan rumah tangga.

Berkualitas tidaknya hidup perempuan pada masa menopouse sangat dipengaruhi oleh respon/reaksi perempuan terhadap fase tersebut. Blackburn membagi reaksi perempuan terhadap menopouse, pertama, reaksi pasif yaitu secara pasrah perempuan menerima hal yang tidak dapat dielakkan lagi. Biasanya ditemukan pada perempuan yang berpendidikan rendah. Kedua reaksi neurosis yaitu reaksi yang timbul oleh penolakan yang keras akan datangnya masa klimakterium ini, ditandai dengan timbulnya keluhan-keluhan seperti rasa cemas, rasa 
tertekan, depresi, dan mudah tersinggung. Ketiga, reaksi hiperaktif yaitu reaksi penolakan dengan seolah-olah mengabaikan datangnya masa klimakterium dengan cara meningkatkan perhatian pada pekerjaan dan hobi, serta tidak setuju pada keluhan perempuan lain. Keempat, reaksi adekuat yaitu reaksi wajar yang diberikan oleh perempuan yang memasuki masa menopouse, biasanya dialami oleh perempuan yang emosionalnya kuat.

Dalam bahasa agama, reaksi adekuat dimanifestasikan dari tindakan memandang menopause sebagai hal yang alamiah/sunnatullah bahkan disyukuri atas kenikmatan yang diberikan Allah, maka individu akan menghadapinya dengan penuh penerimaan dan keikhlasan sehingga berbagai gangguan fisiologis yang dialaminya tidak berdampak pada gangguan psikologis 29 . Studi menunjukkan persoalan-persoalan psikologis yang muncul mengiringi fase menopause sangat efektif jika ditangani dengan pendekatan-pendekatan psikologis pula.

Reaksi neurosis, hiperaktif bahkan sikap pasif, memandang masa menopouse masa yang menakutkan. Sikap ini akhirnya membawa kepada kecemasan yang dapat menimbulkan ketegangan dan konflik batin serta ganguan emosional yang menjadi alasan bagai timbulnya kesehatan mental yang tidak baik. Hasil penelitian menunjukkan bahwa kecemasan yang dirasakan perempuan ketika masa menopouse mengakibatkan dirinya sulit untuk berkosentrasi dalam mengerjakan sesuatu, kesulitan dalam membuat keputusan, mengalami sulit tidur serta munculnya perasaan-perasaan seperti rasa gugup dan panik.

Study yang dilakukan oleh Decey \& Travers menunjukkan bahwa kecemasan yang dialami oleh perempuan selama masa menopouse dipengaruhi oleh sikap perempuan tersebut terhadap menopouse, dimana menopouse sering dilihat sebagai sesuatu yang menakutkan. Kekhawatiran ini berawal dari pemikiran bahwa dirinya tidak sehat, tidak bugar dan tidak cantik lagi. Padahal, masa menopouse merupakan salah satu fase yang harus dijalani seorang perempuan dalam kehidupannya, dan kecemasan yang mereka alami dapat menyebabkan mereka sangat sulit menjalani masa ini ${ }^{30}$

Dengan demikian, agar dapat menjalani masa menopouse dengan baik, diperlukan pemikiran yang positif dalam memandang masa menpouse yang dialami. Sebaliknya apabila orang tersebut berpikir secara negatif tentang menopouse, maka keluhan-keluhan yang muncul akan memberatkannya.

Faktor lain yang dapat mempengaruhi berkualitas tidaknya hidup perempuan yang menopouse adalah dukungan sosial. Dukungan sosial 
merupakan berbagai macam dukungan yang diterima oleh seseorang dari orang lain, dapat berupa dukungan emosional, dukungan penghargaan atau harg diri, dukungan instrumental, dukungan informasi atau dukungan dari kelompok. Adanya dukungan sosial merupakan hal yang sangat penting bagi kesehatan individu. Cobb, dkk dalam Safarino (1998) mengartikan dukungan sosial sebagai bantuan, perhatian, atau kenyamanan yang dirasakan sesorang yang diterimanya dari orang lain ${ }^{31}$

Dukungan sosial dapat mengurangi rasa kecemasan yang dialami oleh perempuan menopouse karena salah satu cara untuk mengatasi kecemasan adalah berbagi dan membicarakan rasa tersebut kepada orang lain. Menurut Kasdu seseorang yang menjalani masa menopouse juga membutuhkan informasi yang benar tentang menopouse karena dengan pengetahuan dan informasi yang benar akan membantu mereka dalam memahami dan mempersiapkan dirinya untuk menjalani menopouse dengan baik. Adanya pemahaman bagaimana menopouse dapat mempengaruhi dirinya, dapat membantu sesorang dalam mengatasi perubahan-perubahan yang mungkin akan terjadi. Selain itu, pengetahuan yang dimiliki oleh sesorang juga dapat mempengaruhi sikapnya terhadap menopouse ${ }^{32}$.

Spencer \& Brown mengemukakan bahwa dengan tetap mempertahankan kehidupan sosial yang aktif akan membantu sesorang dalam mengatasi kesulitan emosi dan perasaan dalam mejalani menopouse. Selain itu, hal yang dibutuhkan oleh sesorang yang mengalami menopouse adalah pengertian dan dukungan dari keluraga dan lingkungan. Menurut Kasdu banyak perempuan dapat memahami gejala-gejala menopouse dan menjalaninya dengan bantuan dan dukungan dari orang-orang di sekitarnya, seperti teman, keluarga khususnya suami ${ }^{33}$.

Pengertian, penerimaan dan dukungan dari suami sangat besar artinya bagi perempuan yang menjalani menopouse. Suami peduli dan perhatian serta dapat diajak berbagi akan membantu sesorang dalam menjalankan masa menopousenya. Perhatian yang diperoleh akan membuatnya merasa berharga dan dicintai oleh pasangannya. Hurlock ${ }^{34}$ juga menyatakan bahwa pada masa ini, terdapat perubahan hubungan dari hubungan yangberpusat pada keluarga (family centered relationship) menjadi hubungan yang berpusat pada pasangan (pair centered relationship), dimana hal ini menunjukkan bahwa peran pasangan amat penting artinya dalam kehidupan.

Komunikasi dan keterbukaan diantaranya dapat membantu sesorang menjalani menopousenya dengan lebih baik.Hal ini dapat terjadi apabila 
permasalahan yang mucul saat menopouse dibicarakan secara bersamasama dan dicari solusinya. Retnowati mengungkapkan bahwa keberadaan, dukungan dan perhatian dari suami dapat membuat seorang perempuan yang menopouse merasa dicintai dan dihargai. Kasdu menyatakan bahwa peran positif dari suami akan membuat seorang perempuan berpikir bahwa kehadirannya masih sangat dibutuhkan dalam menghadapi kehidupan.

Di sisi lain, Retnowati ${ }^{35}$ menyebutkan. Di usia menopouse, biasanya perempuan mempunyai putra-putri yang sudah besar dan dewasa, yang perlahan-lahan mulai memiliki kehidupan sendiri. Ketergantungan mereka terhadap orang tua mulai berkurang sehingga fungsi dan peran orang tua pun tidak sebesar dulu lagi. Bagi perempuan yang terbiasa terlibat secara intens dalam kehidupan anaknya, hal ini merupakan keadaan yang sulit untuk diterima. Disadari atau tidak, pelan-pelan mulai timbul perasaan diabaikan, tidak diperhatikan, tidak berguna/tidak berperan lagi yang kemudian mengarah ke rasa kesepian.

\section{SIMPULAN}

Menopause merupakan salah satu tugas perkembangan perempuan dalam memahami siklus kehidupannya sebagai perempuan. Menyadari kembali eksistensi dirinya sebagai makhluk biopsikososial yang telah melewati fase anak-remaja-dewasa hingga akhirnya fase tua. Menjadi tua adalah sebuah proses kehidupan. Keluhan-keluhan akibat perubahanperubahan fisik yang secara signifikan dengan melakukan sesuatu yang bermakna akan meningkatkan kesejahteran psikologis dan berpengaruh positif terhadap kualitas hidup perempuan.

Penanganan persoalan-persoalan psikologis yang muncul mengiringi fase menopause menjadi sangat efektif jika ditangani dengan pendekatan-pendekatan psikologis. Pentingnnya informasi dan pengetahuan seputar kesehatan reproduksi dan menopause tidak hanya bagi perempuan. Suami, anak-anak dan masyarakat sangat berperan untuk memberikan dukungan secara psikologis dalam menghadapi perubahan-perubahan fisik dan perubahan psikis yang menyertai fase menopause pada perempuan.

Menopause merupakan salah satu proses kehidupan juga tidak dapat dihindari kehadirannya namun juga tidak untuk ditakuti/dikhawatirkan kehadirannya. Demikian pula pada kondisi mental yang tidak stabil dan bergejolak, individu membutuhkan bantuan secara psikologis, untuk memulihkan rasa percaya dirinya, meluruskan cara berfikir, cara pandang dan cara merasanya sehingga mereka kembali 
realistis, mampu melihat kenyataan yang sebenarnya dan mampu mengatasi masalahnya dengan cara-cara yang dapat dipertanggungjawabkan.

Konsep diri positif serta dukungan yang diberikan keluarga maupun teman-teman akan dapat meningkatkan kualitas hidup perempuan menopause. Konsistensi konsep diri akan meningkatkan harmonisasi dalam diri individu yang pada akhirnya akan meningkatkan kebahagiaan individu. Kualitas hidup individu akan meningkat ketika terjadi integrasi antara harga diri, konsep diri, serta adanya penerimaan diri individu dalam memaknai dan menyikapi persoalan hidup.

\section{Endnotes}

1 Manuaba, I.B.O. 1999. Memahami Kesehatan Reproduksi Perempuan. Jakarta: Penerbit Arcan.

2 Kasdu, D. 2002. Kiat Sehat E Bahagia Di Usia Menopause. Jakarta: Puspa Swara

3 Retnowati, S. 2001. Tetap Bergairah Memasuki Usia Menopause: Sebuah Tinjauan Psikologis. Disampaikan pada Seminar Ilmiah Populer dalam Rangka Milad ke 78 RSU PKU Muhammadiyah Yogayakarta, 24 Februari 2001.

4 Manuaba, I.B.O. 1999. Memahami Kesehatan Reproduksi Perempuan. Jakarta: Penerbit Arcan

5 Rahman, I.A.1995, Perubahan Tubuh Menjelang Menopouse \& Gejala serta TandaTanda Menyertainya dalam Simposium Sehari Masalah Seputar Menopouse Serta Penanggulangan bagi Perempuan yang Aktif

6 Kasdu, 2004. Kiat Sehat dan Bahagia di Usia Menopouse, Jakarta: Gramedia

7 Drajat, Z, Menghadapi Masa Menopouse Mendekati Usia Tua,Jakarta : Bulan Bintang

8 Baziad, A, 2002, Seputar Masalah Menopouse, www.klinik.perempuan.com

9 Takesihaeng, J, 2000, Hidup Sehat bagi Perempuan, Jakarta: Gramedia

10 Blackburn \& Davidson, 1990, Terapi Kognitif untuk Depresi \& Kecemasan Suatu Petunjuk Suatu Petunjuk

11 Halim, S. 1996. Memelihara Kesehatan Reproduksi. Jakarta: Obor.

12 Papalia, Olds, dan Feldman. 1998. Psikologi Pekembangan. Bandung: Rineka Cipta.

13 Manuaba, I.B.O. 1999. Memahami Kesehatan Reproduksi Perempuan. Jakarta: Penerbit Arcan

14 Ibrahim. 2005. Psikologi perempuan. Bandung: Pustaka Hidayah

15 http://menoherbs.org/tag/menopause, 2012

16 Blackburn \& Davidson, 1990, Terapi Kognitif untuk Depresi \& Kecemasan Suatu Petunjuk Suatu Petunjuk bagi Praktisi, Semarang : IKIP Semarang

17 Prawasti, D. 2007. Hubungan Antara Gejala-Gejala Menopause dan Kepuasan Perkawinan Pada Perempuan. Skripsi. Jakarta: Fakultas Psikologi Universitas Indonesia. Tidak Diterbitkan.

18 Prawasti, D. 2007. Hubungan Antara Gejala-Gejala Menopause dan Kepuasan Perkawinan Pada Perempuan. Skripsi. Jakarta: Fakultas Psikologi Universitas Indonesia. Tidak Diterbitkan

19 http://togeler.dot.web.id/2012/09/7-mitos-keliru-soal-menopause.html

20 Sarafino, E.P.1994, Healthy Psychologi, 2nd ed.new York :John Qishi Press

21 Sarafino, E.P.1994, Healthy Psychologi, 2nd ed.new York :John Qishi Press 
${ }^{22}$ Kreitler \& Ben, 2004, Quality of Life in Children, New York: John Wiley n Son

${ }^{23}$ Edisia Sekarwani, Hubungan antara Kualitas Hidup dan Sens of Community, www.digilib.ui.co.id

24 Poerwandari, K, 1998, Pendekatan Kualitatif dalam Penelitian Psikologi, Jakarta: Lembaga Pengembangan Sarana Pengukuran \& Pendidikan Psikologi (LPSP 3) Universitas Indonesia

$25 \mathrm{http} /$ / suara merdeka. "peranan seksologi dalam membina keharmonisan rumah tangga sejahtera. diunduh 1 oktober 2012.

${ }^{26}$ Hawari, D. 1996. Al Qur'an: Ilmu Kedokteran Jiwa dan Kesehatan Jiwa. Yogyakarta: PT.Dana Bhakti Prima Yasa.

27 Coob, J, 1993,Understanding Menopouse, London : British Medical

28 Dimsdale, 1995, Quality of Life in Behavioral Medicine Reseach, New Jersey : Lawrence Exibaum, Associates Publisher

29 Retnowati, S. 2001. Tetap Bergairah Memasuki Usia Menopause: Sebuah Tinjauan Psikologis. Disampaikan pada Seminar Ilmiah Populer dalam Rangka Milad ke 78 RSU PKU Muhammadiyah Yogayakarta, 24 Februari 2001.

30 Kasdu, 2004. Kiat Sehat dan Bahagia di Usia Menopouse, Jakarta: Gramedia

31 Manuaba, I.B.O. 1999. Memahami Kesehatan Reproduksi Perempuan. Jakarta: Penerbit Arcan

32 Kasdu, 2004. Kiat Sehat dan Bahagia di Usia Menopouse, Jakarta: Gramedia

33 http://menoherbs.org/tag/menopause, 2012)

${ }^{34}$ http://menoherbs.org/tag/menopause, 2012)

35 Retnowati, S. 2001. Tetap Bergairah Memasuki Usia Menopause: Sebuah Tinjauan Psikologis. Disampaikan pada Seminar Ilmiah Populer dalam Rangka Milad ke 78 RSU PKU Muhammadiyah Yogayakarta, 24 Februari 2001

\section{DAFTAR PUSTAKA}

Cross, Susan E., Gore J.s., \& Morris, M.L. 2003. The relational Interdependent Self-Construal, Self Concept Consistency \& Well Being. Journal of Personality E Social Psychological, 85, (5)

Daradjat, Z. 1994. Menghadapi Masa Menopause, Mendekati Usia Tua. Jakarta: Bulan Bintang.

Erika. 2009. http://menopause/gejala/perempuan/. Kesehatan Reproduksi Perempuan Menopause Diunduh 19 Juni 2012

Halim, S. 1996. Memelihara Kesehatan Reproduksi. Jakarta: Obor.

Hawari, D. 1996. Al Qur'an: Ilmu Kedokteran Jiwa dan Kesehatan Jiwa. Yogyakarta: PT.Dana Bhakti Prima Yasa.

http//suara merdeka. "peranan seksologi dalam membina keharmonisan rumah tangga sejahtera. diunduh 1 oktober 2012

http://menoherbs.org/tag/menopause, 2012

Ibrahim. 2005. Psikologi perempuan. Bandung: Pustaka Hidayah 
Kartono, K. 1992. Psikologi Perempuan, Jilid 2, Mengenal Perempuan Sebagai Ibu $\mathcal{E}$ Nenek. Bandung: Mandar Maju

Kasdu, D. 2002. Kiat Sehat E Bahagia Di Usia Menopause. Jakarta: Puspa Swara

Keputusan Menteri Pemberdayaan Perempuan dan Perlindungan Anak tahun 2008 Pasal 1

Kreitler \& Ben .2004. Quality of life in children. New York: JohnWiley \& Sons

Larasati. 2009. Kualitas Hidup Pada Perempuan Yang Sudah Memasuki Masa Menopause. Jurnal. Fakultas Psikologi Universitas Gunadarma, Jakarta

Manuaba, I.B.O. 1999. Memahami Kesehatan Reproduksi Perempuan. Jakarta: Penerbit Arcan

Mappiare, A. 1983. Psikologi Orang Dewasa. Jakarta: Mandar Maju

Palupi, Sri. 2006. Islam dan Menopause: Urgensitas Bimbingan dan Konseling Islam Bagi Persoalan Psikologis Perempuan Menopause. Disampaikan pada Annual Conference Kajian Islam

Papalia, Olds, dan Feldman. 1998. Psikologi Pekembangan. Bandung: Rineka Cipta

Prawasti, D. 2007. Hubungan Antara Gejala-Gejala Menopause dan Kepuasan Perkawinan Pada Perempuan. Skripsi. Jakarta: Fakultas Psikologi Universitas Indonesia. Tidak Diterbitkan

Reber, E.M., Reber, A.S. 2010. Kamus Psikologi. Yogyakarta: Pustaka Pelajar

Retnowati, S. 2001. Tetap Bergairah Memasuki Usia Menopause: Sebuah Tinjauan Psikologis. Disampaikan pada Seminar Ilmiah Populer dalam Rangka Milad ke 78 RSU PKU Muhammadiyah Yogayakarta, 24 Februari 2001 